\title{
Sistem Pendukung Harga Saham dengan Metode Linear Regression dan Simple Keputusan untuk Prediksi
}

\author{
Ilham Nefriardo Armaz ${ }^{1)}$, Harfebi Fryonanda ${ }^{2)}$ \\ 1) Sistem Informasi, Fakultas Industri Kreatif \\ Jalan Pulomas Selatan Kav.22, Jakarta Timur 13210 \\ Email: ilham.nef@gmail.com \\ Email: harfebi.fryonanda@kalbis.ac.id
}

\begin{abstract}
This research is conducted to solve existing problems in the stock market such as fluctuating prices and decisions to be taken on the stock market. A common problem encountered is the difficulty of knowing stock price trends over a given period and using the analysis used in the stock market. Technical analysis allows to know stock market price based on trend by using Simple Moving Average which have accuracy level 96,39 and Linear Regression which have accuracy level 94,91. The purpose of this research to produce decision support system that can be used as a prediction with the method of Simple Moving Average and Linear Regression that can be compared the level of accuracy. This application is a solution to determine the stock price prediction in a certain period.
\end{abstract}

Keywords: decision support system, linear regression, prediction, simple moving average, stock price

\begin{abstract}
Abstrak: Penelitian ini dilakukan untuk memecahkan permasalahan yang ada di pasar saham seperti harga yang flukuatif dan keputusan yang akan diambil pada pasar saham. Masalah umum yang dihadapi adalah sulitnya mengetahui tren harga saham selama periode tertentu dan menggunakan analisis yang digunakan di pasar saham. Analisis teknis memungkinkan untuk mengetahui harga pasar saham berdasarkan tren dengan menggunakan Simple Moving Average yang memiliki tingkat akurasi 96,39 dan Linear Regression yang memiliki tingkat akurasi 94,91. Tujuan dari penelitian ini menghasilkan sistem pendukung keputusan yang dapat digunakan sebagai prediksi dengan metode Simple Moving Average dan Linear Regression yang dapat dibandingkan tingkat akurasinya. Aplikasi ini merupakan solusi untuk mengetahui prediksi harga saham dalam suatu periode tertentu.
\end{abstract}

Kata kunci: harga saham, linear regression, prediksi, simple moving average, sistem pendukung keputusan.

\section{PENDAHULUAN}

Pada era globalisasi saat ini kemajuan akan perkembangan teknologi semakin cepat yang melibatkan negara-negara di dunia. Perkembangan yang sangat pesat mempengaruhi hampir dalam berbagai bidang khususnya pada bidang sistem informasi manajemen. Globalisasi dapat diartikan sebagai proses interaksi dan integrasi antara orangorang, perusahaan, dan pemerintah dari berbagai negara, tanpa adanya lagi batasan-batasan untuk dapat berkembang mengikuti era global[1].

Berkembangnya sistem informasi khususnya yang ada di Indonesia mendorong berbagai pihak untuk dapat menerapkannya diantaranya pada bidang ekonomi, pendidikan kesehatan dan sebagainya. Sistem Informasi Manajemen merupakan sistem yang mengumpulkan, menjalankan, menyimpan, menganalisis, dan menyebarkan informasi dengan tujuan yang spesifik[2]. Sistem informasi tidak terlepas dari sumber daya manusia yang handal dan pendukung keputusan sehingga terciptanya sistem informasi yang dapat menyelesaikan permasalahan yang dihadapi.

Dalam penerapan sebuah keputusan memerlukan proses yang harus dilalui terlebih dahulu sebelum keputusan diterapkan. Sistem pendukung keputusan merupakan sebuah sistem yang digunakan untuk mendukung para pengambil keputusan manajerial dalam situasi keputusan semiterstruktur namun tidak untuk menggantikan peran penilaian mereka[3]. Sistem keputusan dapat diterapkan pada berbagai bidang seperti sosial[4], pendidikan[5] dan ekonomi[6]. Dari beberapa beberapa bidang yang ada untuk menerapkan sistem keputusan, penulis berasumsi pengambilan keputusan dapat dilakukan pada bidang ekonomi khususnya dan pada sektor pasar saham. 
Pasar saham merupakan tempat dimana perusahaan menjual saham dan obligasi dengan tujuan dari hasil penjualan tersebut nantinya akan dipergunakan untuk mendukung keuangan perusahaan[7]. Investasipada pasarsaham dipengaruhi oleh beberapa faktor seperti informasi pasar, risiko investasi, dan kebijakan pada perusahaan[8]. Dalam pasar saham terdapat metode yang memprediksi berdasarkan data-data harga pada pasar saham. Pada penelitian yang dilakukan oleh Yanuar Metode Simple Moving Average dapat dikatakan memiliki hasil yang lebih baik dibandingkan dengan Exponential Moving Average[9], Sedangkan pada penelitian yang dilakukan oleh Lim Sany yang membandingkan metode prediksi yang ada, dapat dikatakan hasil prediksi dengan menggunakan Linear Regression membuktikan hasil yang lebih baik[10].

Sebuah hasil prediksi memerlukan perbandingan untuk melengkapi hasil prediksi yang ada. Hasil dari sebuah prediksi dapat dijadikan sebuah pendukung keputusan berdasarkan penghitungan yang sudah dilakukan dan dapat dijadikan alternatif untuk mendapatkan hasil terbaik sebelum kepeutusan akhir dapat diterapkan.

\section{METODE PENELITIAN}

Metode penelitian merupakan gambaran alur langkah-langkah yang digunakan untuk mencapai tujuan atas permasalahan yang diteliti. Berdasarkan penelitian yang digunakan, penelitian ini menggunakan metode prediksi Simple Moving Average dan Linear Regression. Metode Simple Moving Average dan Linear Regression digunakan untuk mendapatkan hasil prediksi terbaik untuk diterapkan pada pasar saham. Proses - proses tersebut digambarkan dalam bentuk diagram alir yang bertujuan untuk menggambarkan tahapan yang harus

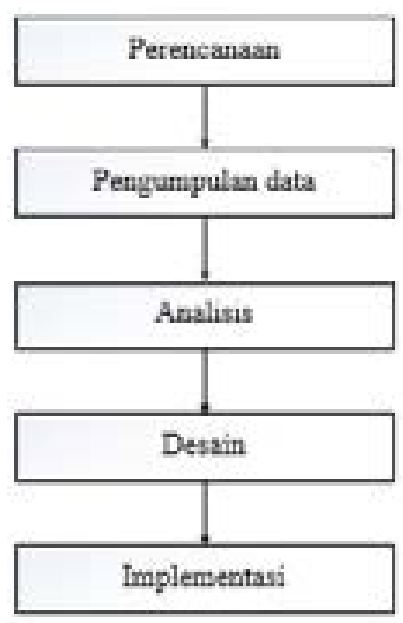

Gambar 1 Alur Penelitian dikerjakan yang dapat dilihat pada Gambar 1 .

Penjelasan langkah-langkah yang dilakukan untuk melakukan penelitian prediksi harga saham, seperti yang digambarkan pada Gambar 1 .

\section{Perencanaan}

Tahapan ini dilakukan agar proses penelitian berjalan dengan baik dan terstruktur. Berikut ini yang termasuk di dalam perencanaan adalah sebagai berikut: a). Studi Literatur. Selanjutnya peneliti melakukan studi literatur yang terdapat pada jurnal, buku dan penelitian terkait seperti pada penelitian yang dilakukan oleh yanuar dengan penelitiannya perbandingan efisiensi teknikal indikator Simple Moving Average dan Exponential Moving Average Pada pertambangan batubara di bursa efek indonesia [9] dan penelitian yang dilakukan oleh lim sanny dengan penelitiannya peramalan jumlah siswa sekolah menengah atas swasta menggunakan metode forecasting[10] yang juga menggunakan Linear Regression dalam penelitiannya.

\section{Pengumpulan Data}

Pada tahapan ini merupakan teknik pengumpulan data yang dilakukan oleh peneliti dalam melakukan penelitian yaitu: a). Observasi. Penulis melakukan observasi terhadap data saham yang terdapat pada Bursa Efek Indonesia untuk mendapatkan data yang terkait dengan penelitian. dan b). Wawancara. Penulis melakukan wawancara terhadap pengguna untuk mengetahui kebutuhan yang dibutuhkan pengguna terhadap sistem yang akan dibangun.

3. Analisis

Tahapan analisis peneliti melakukan analisis terhadap data yang didapatkan. Fase ini juga menganalisis data yang sudah di dapatkan dan kebutuhan lainnya yang diperlukan dalam proses penelitian. Dalam kegiatan penelitian ini terdapat 2 jenis analisis kebutuhan yaitu: a). Kebutuhan Data Fungsional. Kebutuhan fungsional adalah kebutuhan yang memiliki hubungan secara langsung dengan sebuah sistem. Kebutuhan fungsional yang terdapat pada aplikasi ini meliputi kebutuhan admin dan user sebagai pengguna. Adapun kebutuhan fungsional dapat dilihat pada Tabel 1; dan b). Kebutuhan Data Tabel 1. Kebutuhan Fungsional

\begin{tabular}{|c|c|}
\hline$\overline{\text { Ciser }}$ & Ketutibuta \\
\hline Invertor & 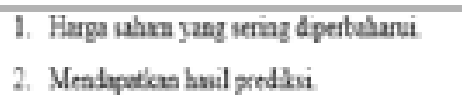 \\
\hline Absin & 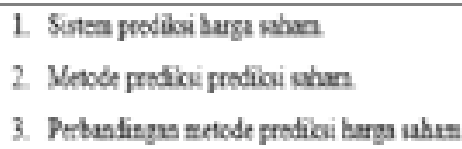 \\
\hline
\end{tabular}


Non Fungsional. Kebutuhan data non-fungsional merupakan kebutuhan yang tidak berhubungan langsung dengan fitur-fitur yang ada pada sistem yang dibagi menjadi dua yaitu 1). Perangkat keras yang digunakan: a). Processor Intel Core i3, b). Harddisk 500GB, c). Ram 4GB, d). Vga Nvidia GTX 660 2GB dan e). perangkat standar input dan output, dan 2). Perangkat lunak yang digunakan dalam membangun sistem ini: a) Sistem Operasi Windows, b). Database Server(MySQL server) dan c). Program Editor (Netbeans IDE).

\section{Desain}

Dalam perancangan sistem terdiri dari proses perancangan database dan perancangan antarmuka.

\section{Desain}

Tahapan ini merupakan tahapan dimana penulis mengimplementasikan rancangan yang sudah dibuat pada tahapan desain. Pada tahapan ini penulis membuat program dengan bahasa pemrograman Java. Sistem prediksi harga saham ini terdiri dari halaman login user, halaman login admin, halaman uatam user dan halaman khusus admin.

\section{A. Use Case Digram}

Use diagram menggambarkan sistem yang akan dibangun oleh peneiliti. Berikut ini merupakan use case diagram pada sistem seperti pada Gambar 2.

Gambar 2 merupakan penjelasan mengenai sistem yang akan dibangun oleh peneliti. Admin atau penulis menginput data harga saham yang sudah beredar dan mengolah linrstdata yang dirilis bursa efek sehingga data yang ada dapat disajikan dengan baik. Admin dapat mengawasi kegiatan yang dilakukan pengguna sehingga sistem dapat berjalan dengan baik

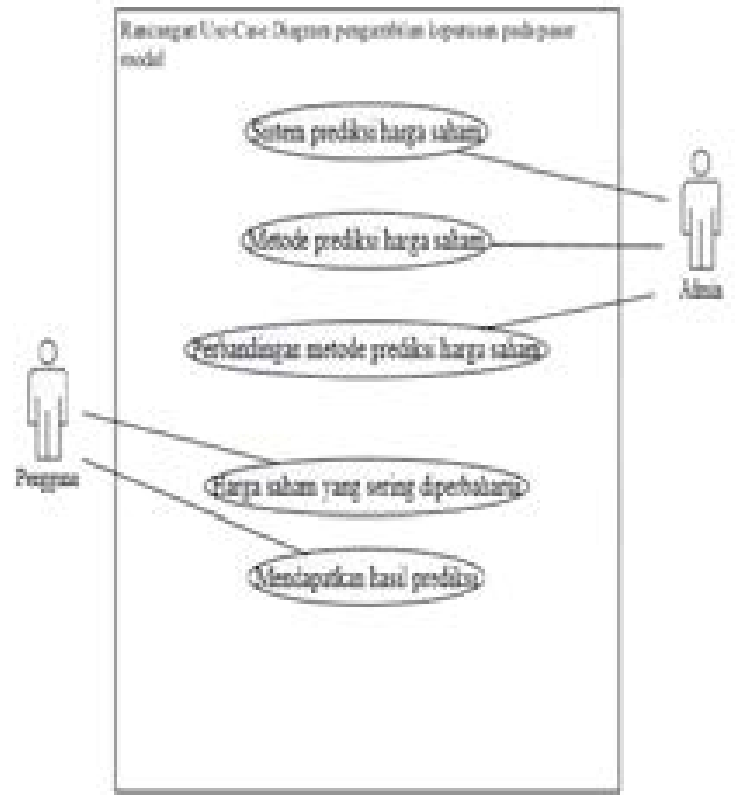

Gambar 2 Rancangan Use Case Diagram dan segera diketahui apabila ada permasalahan dalam sistem. Pihak investor atau user dapat melihat harga pada pasar saham dan mendapatkan ahsil keputusan berupa prediksi harga saham.

\section{B. Flow Chart}

Diagram alir menggambarkan tahapan setiap aktifitas yang dilakukan oleh sistem yang akan dibangun oleh peneiliti. Sistem yang akan dibangun oleh peneliti menggandung beberapa sisi yang berperan dalam menunjang proses berjalannya sistem dengan baik diantaranya seperti: a). Bursa Eek. Berperan dalam merilis daftar harga saham ke publik. Apabila data sudah dirilis oleh bursa efek, data tersebut dapat di unduh, b). Admin. Admin bertugas dalam melakukan pengunduhan data dan memasukannya ke dalam sistem. Admin juga menawarkan sistem tersebut kepada investor, c). Sistem. Fungsi utama yang menjalankan beberapa tugas seperti penyimpanan data saham, menampilkan harga saham, memberikan keputusan dan memberikan alternatif keputusan, dan d). Investor. Merupakan pengguna dari sistem yang dibuat oleh peneliti, Seperti yang terdapat pada Gambar 3 .

\section{Sequence Diagram}

Penulis menggambarkan sequence diagram untuk yang akan dibangun oleh peneliti pada sistem

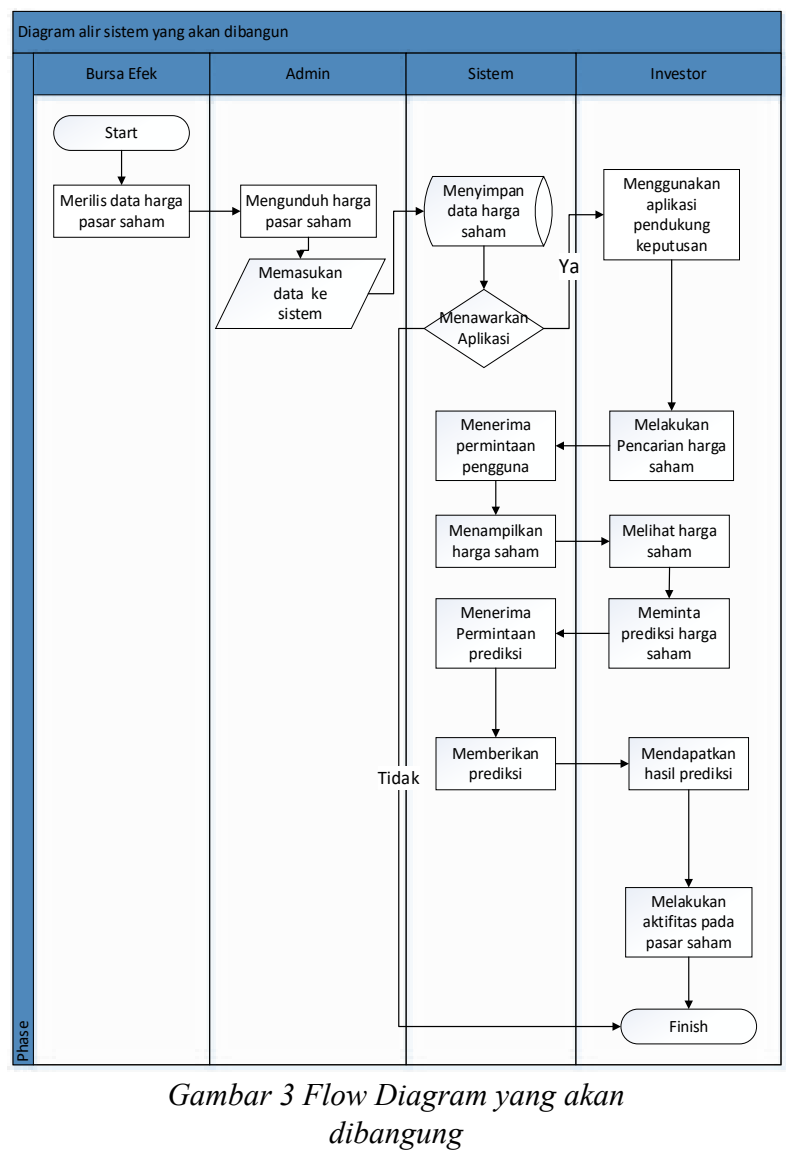




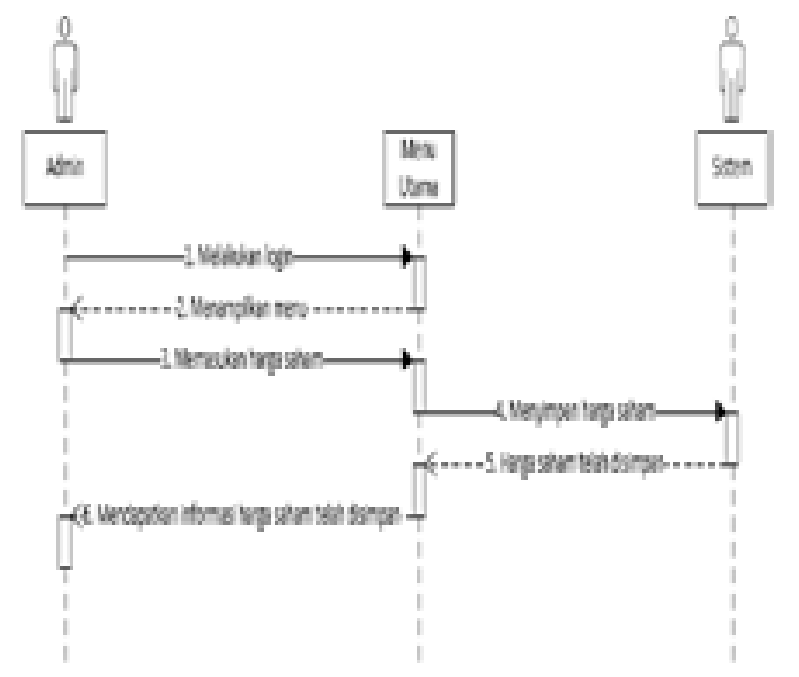

Gambar 4 Sequence Diagram Admin

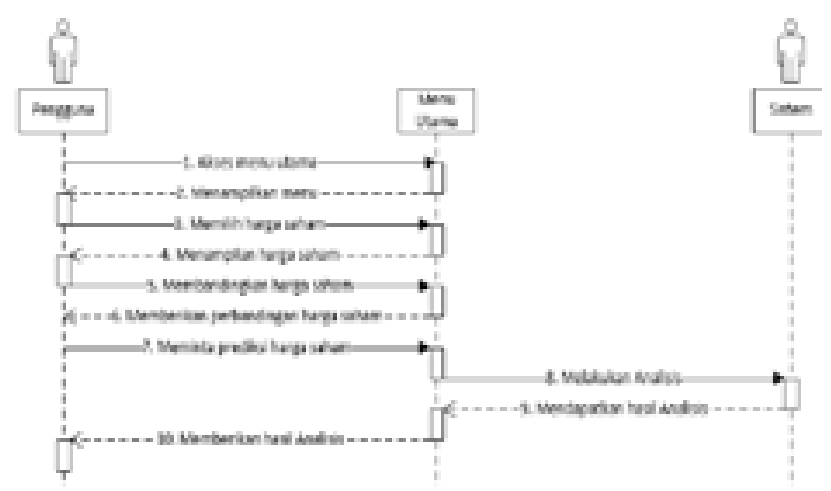

Gambar 5 Sequence Diagram User.

yang baru. Sequence diagram dibagi menjadi dua yaitu a). Sequence diagram admin yang dapat dilihat pada Gambar 4.

Peneliti membuat terlebih dahulu sequence diagram untuk admin. Admin dan sistem sebagai actor utama, setelah admin melakukan login selanjutnya admin memasukan data harga saham kedalam sistem dan mendapatkan informasi bawah harga saham telah disimpan oleh sistem, setelah itu penulis membuat sequence diagram user seperti pada Gambar 5.

Dalam Sequnce diagram user menggambarkan kegiatan yang dilakukan oleh pengguna. Dimulai dari menampilkan harga saham, melakukan perbandingan harga saham dan mendapatkan hasil keputusan harga saham

\section{Class Diagram}

Merupakan class diagram yang dibuat oleh peneliti dalam membangun sebuah sistem pendukung keputusan. Pada gambar 6 menjelaskan keterkaitan antar tabel yang berada pada sistem pendukung keputusan. Beberapa admin dapat memasukan satu harga saham dan satu harga harga saham seperti bbca dapat menyimpan harga saham yang dimasukan oleh beberapa admin, dan tabel-tabel harga saham yang

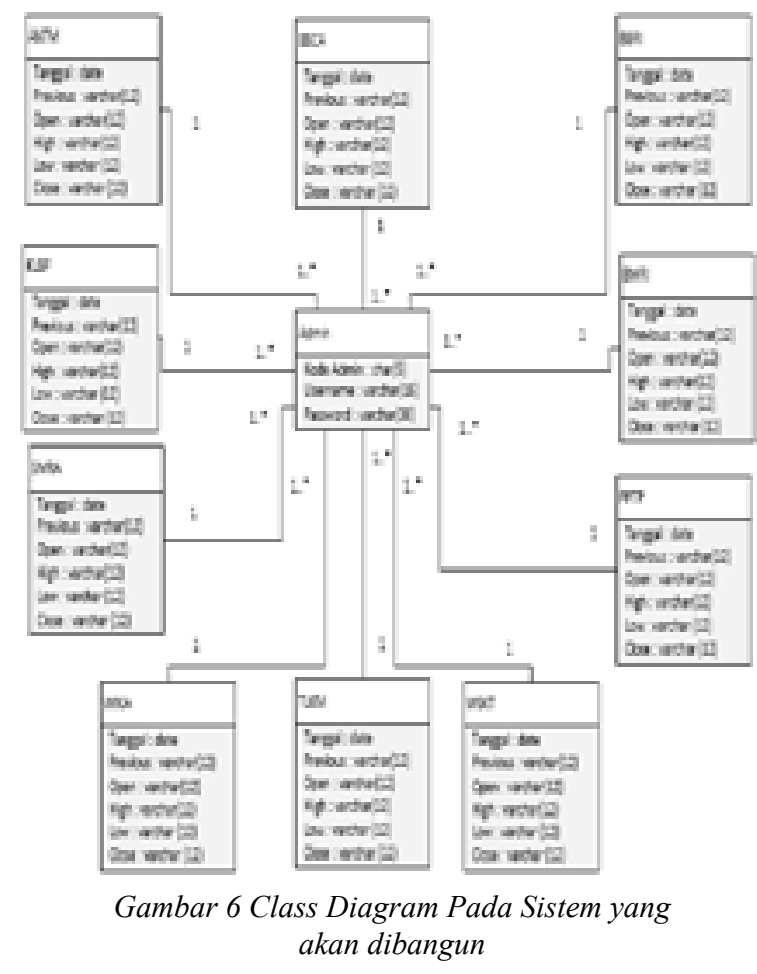

lainnya memiliki relasi yang tidak jauh berbeda dengan tabel saham bbca.

\section{E. Rancangan Antar Muka}

Sistem ini terdiri dari 2 pengguna utama yaitu pengguna dan penulis sebagai admin. Pada halaman login pengguna dapat memilih untuk login sebagai user atau admin jika pengguna, dapat langsung login sebagai user. Pada Gambar 7 dapat dilihat pengguna dapat langsung memilih tombol user dan dapat langsung masuk kedalam sistem. User tidak dapat mendaftarkan sebagai admin karena hanya admin yang dapat menambahkan seorang admin baru.

sebelum masuk kedalam sistem seorang admin harus melakukan login terlebih dahulu, hal ini dilakukan agar admin dapat menambahkan data harga saham. Halaman login admin dapat dilihat pada Gambar 8.

Halaman register new admin merupakan halaman khusus admin. Seorang admin dapat

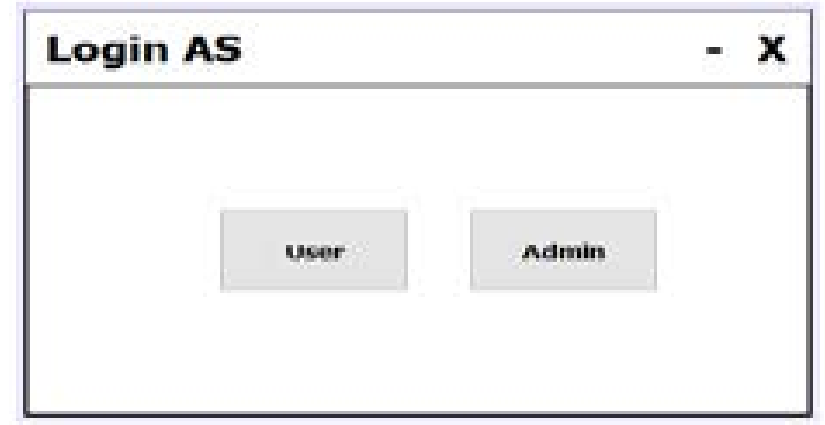

Gambar 7 Desain Halaman Login User 


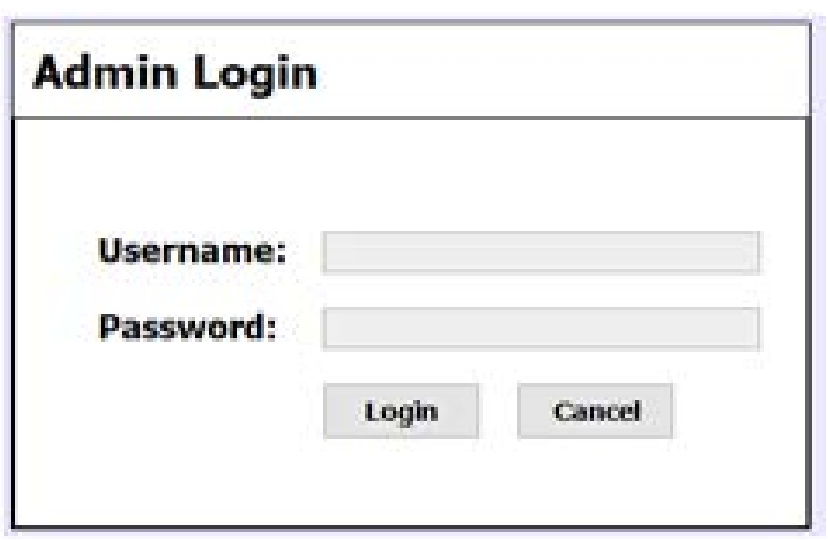

Gambar 8 Desain Halaman Login Admin

menambahkan admin baru, yang berfungsi untuk mempermudah admin dalam melakukan proses memasukan data harga saham seperti pada Gambar 9.

Halaman input admin merupakan tempat dimana seorang admin dapat melakukan input data harga saham. Pada halaman ini nantinya seorang admin dapat melakukan aktifitas seperti insert, update, delete dan reset pada setiap tabel harga saham. Admin dapat melakukan aktifitas lainnya seperti mengunduh data pada tabel saham kedalam komputer seperti pada Gambar 10.

Pada Gambar 11 merupakan halaman utama user yang terdapat beberapa table yang berisikan daftar

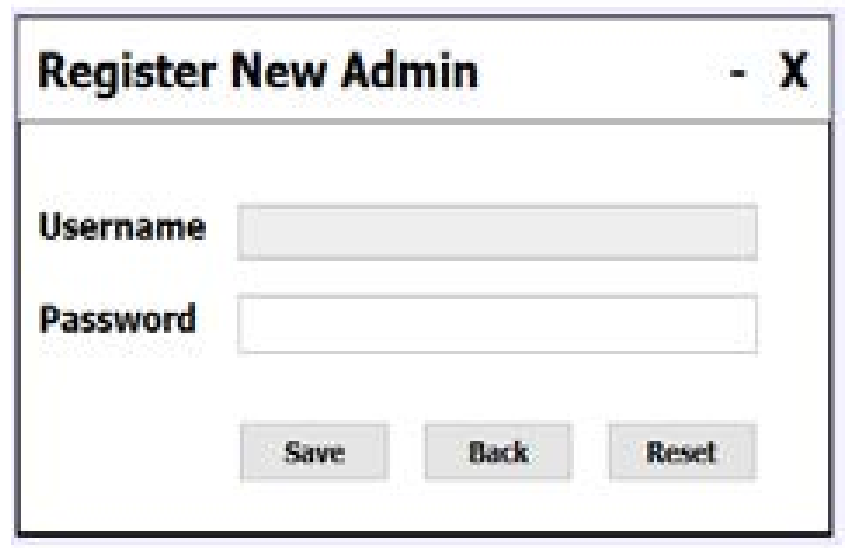

Gambar 9 Desain Halaman Register Admin

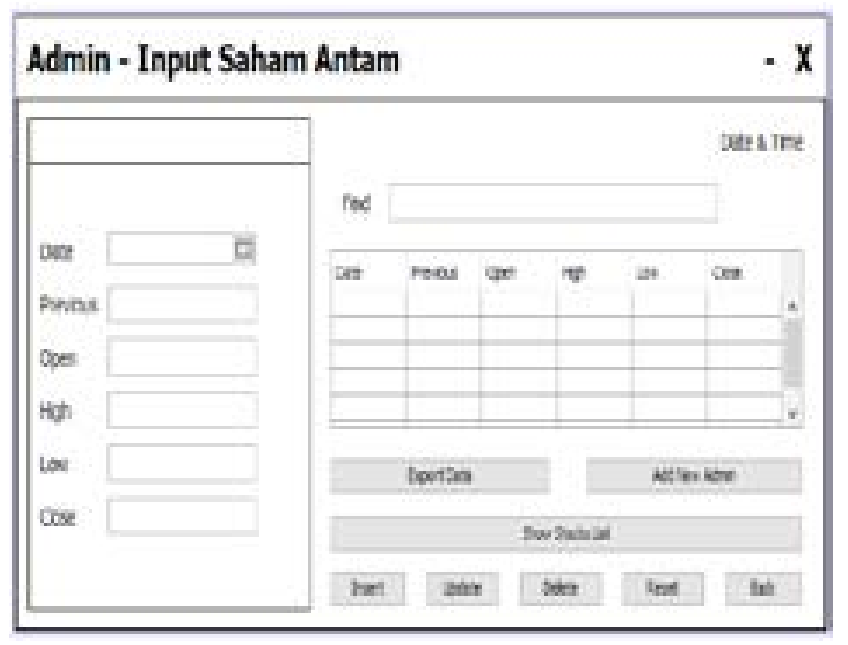

Gambar 10 Desain Halaman Input Admin

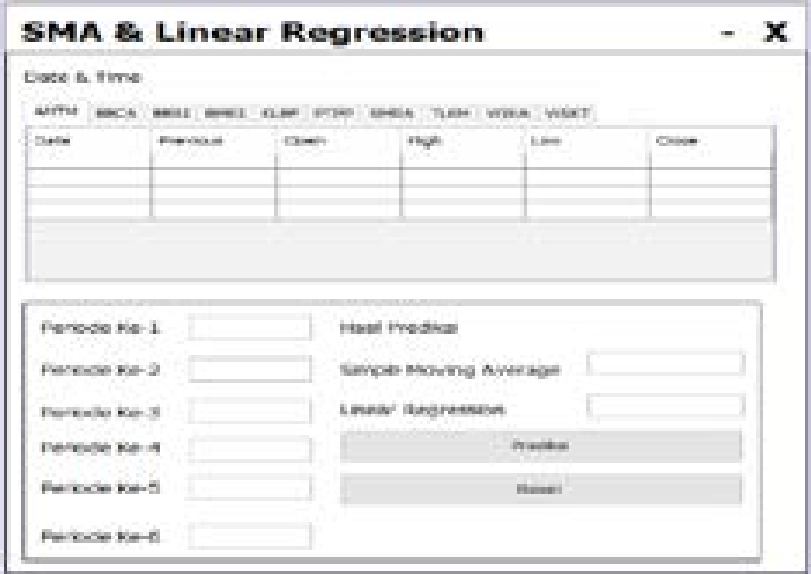

Gambar 11 Interface Utama User

harga saham. Tabel tersebut menampilkan harga pada saat penutupan hari sebelumnya, pada saat pembukaan harga saham, pada saat harga saham tertinggi, pada saat harga saham terendah dan penutupan harga saham. Di halaman ini user dapat melakukan input pada periode textfield yang disediakan dan akan mendapatkan hasil prediksi dengan metode Simple Moving Average dan Linear Regression.

\section{HASIL DAN PEMBAHASAN}

\section{A. Sistem Informasi}

Sistem informasi memiliki beberapa defenisi, beberapa ahli mengemukakan sistem informasi adalah rangkaian prosedur normal dimana data yang ada dikelompokan, diproses menadi informasi dan didistribusikan kepada pengguna[11].Sistem informasi juga dapat diartikan sebagai kerangka kerja yang mengorganisasikan sumber daya (manusia) untuk mengubah masukan (input) menjadi keluaran(output),yang bertujuan mencapai sasaran perusahaan[12]. Dengan pendapat ahli di atas penulis menyimpulkan sistem informasi sebagai sekumpulan dari komponen-komponen yang telah dikelompokan dan saling terintegrasi guna mencapai tujuan dalam organisasi.

\section{B. Sistem Pendukung Keputusan}

Sistem pendukung keputusan atau decision support system merupakan sistem informasi berbasis komputer yang fleksibel, interaktif dan dapat diadaptasi, yang dikembangkan untuk mendukung solusi dalam menyelesaikan masalah manajemen yang tidak terstruktur. Sistem pendukung keputusan menggunakan data dan memberikan antarmuka pengguna yang mudah[13].Sistem pendukung keputusan dapat didefenisikan sebagai sistem yang mendukung seorang manajer dalam memecahkan 
masalah semi-terstruktur dengan cara memberikan informasi ataupun usulan yang mengarahkan pada keputusan tertentu[14]. Penulis menyimpulkan sistem pendukung keputusan adalah sebuah sistem yang digunakan untuk mendukung para pengambil keputusan.

\section{Pasar Modal}

Pasar modal merupakan sebagaimana pasar pada umumnya adalah tempat yang mempertemukan penjual dan pembeli yang membedakannya adalah objek yang diperjual belikan[15]. Pasar modal atau Capital Market dapat diartikan sebagai suatu bidang usaha perdagangan surat-surat berharga seperti saham, sertifikat saham dan obligasi atau efek pada umumnya[16].

\section{Simple Moving Average}

Simple Moving Average merupakan salah satu indikator yang digunakan untuk menghitung harga, dan memiliki rumus [9], salah satunya dapat diterapkan pada pasar saham yang memiliki rumus seperti persamaan(1) .

$$
S M A_{(n)}=\frac{p n+\cdots+P_{2}+P_{1}}{n}
$$

Keterangan :

SMA(n) : rata-rata bergerak sederhana $\mathrm{n}$ hari perdagangan sebelumnya

pn : harga saham $n$ hari sebelumnya

$\mathrm{p}_{2}$ : harga saham 2 hari sebelumnya

$\mathrm{p}_{1}$ : harga saham 1 hari sebelumnya

$\mathrm{n}$ : lamanya hari

\section{F. Linear Regression}

Linear Regression merupakan salah satu metode untuk meprediksi [17]. Yang memiliki rumus seperti rumus persamaan $(2,3,4)$.

Mencari Nilai b

$\mathrm{b}=\frac{\sum X Y-n X Y^{2}}{\sum X^{2}-n X^{2}}$

Kemudian

$\mathrm{a}=\mathrm{Y}-\mathrm{bX}$

Sehingga didapatkan

$$
\mathrm{Y}=\mathrm{a}+\mathrm{bX} \ldots(4)
$$

Regresi linear memiliki keterangan seperti yang diungkapkan oleh [17]. $\mathrm{Y}$ :nilai yang diramalkan

a :konstanta (intercept) $\mathrm{b}$ :koefisien regresi (slope)

bX:koefisien regresi (slope) dan variable yang mempengaruhi (waktu: tahun, bulan, hari)

XY:variable yang mempengaruhi (waktu: tahun, bulan, hari) dan nilai yang diramalkan

$\mathrm{nXY}$ :jumlah data, variable yang mempengaruhi (waktu: tahun, bulan, hari) dan nilai yang diramalkan dikuadratkan

$\mathrm{nX}^{2}$ :jumlah data dan variable yang mempengaruhi (waktu: tahun, bulan, hari)

$\mathrm{X}^{2}$ :jumlah data dan variable yang mempengaruhi (waktu: tahun, bulan, hari) dikuadratkan

\section{G. Mean Absolute Deviation}

Untuk mengetahui tingkat akurasi peneliti menggunakan Mean Absolute Deviation (MAD). Mean Absolute Error adalah metode untuk mengukur ketepatan ramalan dengan rata-rata kesalahan. Yang memiliki rumus seperti[18].

$$
\mathrm{MAD}=\sum\left|\frac{A t-F t}{n}\right| \ldots
$$

Mean Absolute Deviation memiliki keterangan seperti yang diungkapkan oleh [18].

At: data aktual pada periode $t$

$\mathrm{Ft}$ : nilai peramalan pada periode $\mathrm{t}$

$\mathrm{n}$ : jumlah data

\section{H. Mean Absolute Percentage Error}

Mean Absolute Percentage Error (MAPE) merupakan salah satu penghitungan kesalahan yang menghitung ukuran persentase penyimpang antara data aktual dengan data ramalan yang memeliki rumus seperti [19].

$$
\text { MAPE }=\left(\frac{100}{n}\right) \sum \frac{|X t-F t|}{X t} \ldots
$$

Keterangan :

$\mathrm{Xt}$ : data aktual pada periode $\mathrm{t}$

$\mathrm{Ft}$ : nilai peramalan pada periode $\mathrm{t}$

n : jumlah data

I. Hasil Aplikasi

1. Tampilan Halaman Login

Pada tampilan utama yang bisa dilihat pada Gambar 12. Pada Halaman ini pengguna dapat memilih sebagai apa seorang pengguna dapat masuk kedalam sebuah sistem. Pengguna dapat langsung masuk sebagai pengguna untuk dapat melanjutkan ke halaman berikutnya.

\section{Tampilan Halaman Login Admin}

Pada tampilan halaman ini merupakan halaman yang dikhususkan untuk admin yang dapat dilihat 


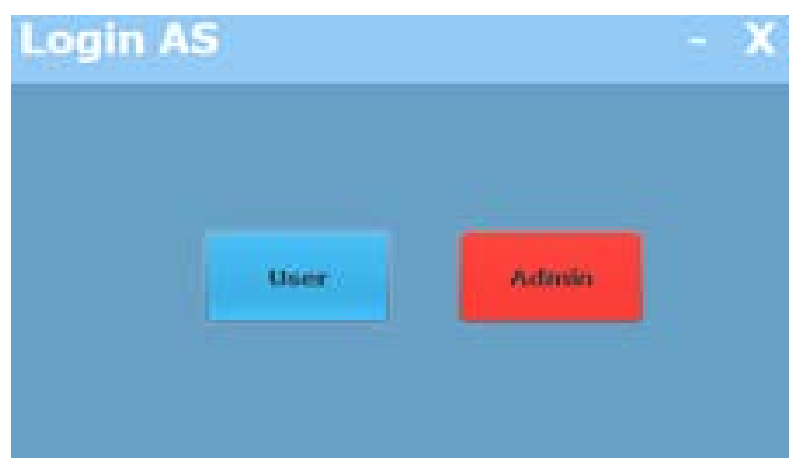

Gambar 12 Halaman pengguna untuk masuk kedalam sistem

pada Gambar 13 pengguna bisa mengakses halaman ini tapi tidak dapat masuk kedalam sistem sebagai admin. Seorang admin bertugas dalam melakukan input data.

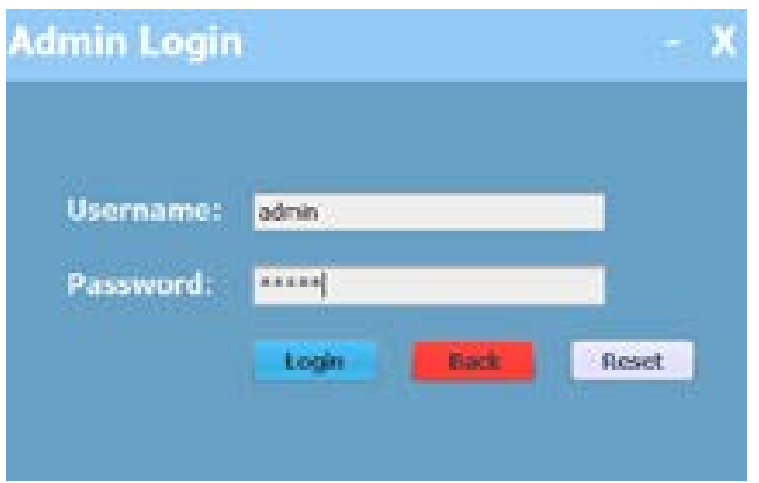

Gambar 13 Halaman admin sebelum masuk kedalam sistem

\section{Tampilan Halaman Penambahan Admin Baru}

Pada tampilan halaman ini merupakan halaman yang dikhususkan untuk admin dalam menambahkan admin baru yang dapat dilihat pada Gambar 14. Admin dapat menambahkan admin baru untuk memudahkan dalam melakukan input data.

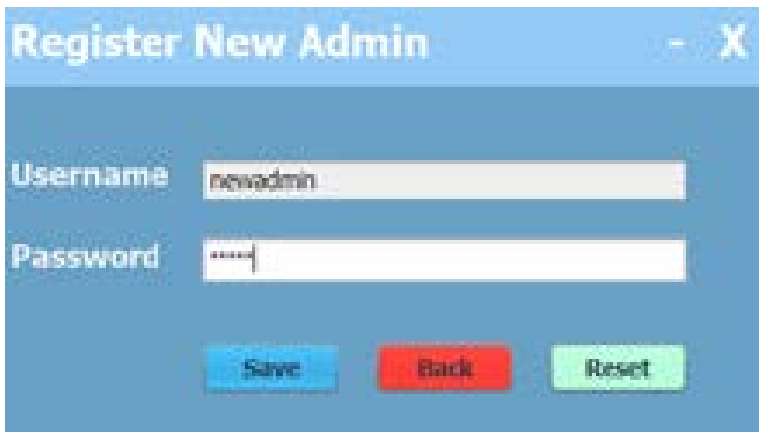

Gambar 14 Halaman admin untuk menambahkan admin baru

\section{Tampilan Halaman Input Data Admin}

Pada Halaman ini merupakan halaman yang digunakan seorang admin dalam melakukan input data yang dapat dilihat pada Gambar 15. Halaman yang digunakan untuk melakukan input secara default mengarah untuk data harga saham pada perusahaan antam. Pada halaman ini terdapat field yang berfungsi sebagai tempat admin dalam memasukan data dan terdapat sebuah tabel yange terhubung ke database untuk melihat apakah data tersebut sudah berhasil dimasukan kedalam database. Pada halaman ini seorang admin dapat melakukan perintah update untuk memperbaharui nominal harga saham yang telah dimasukan dan delete untuk menghapus data pada tabel.

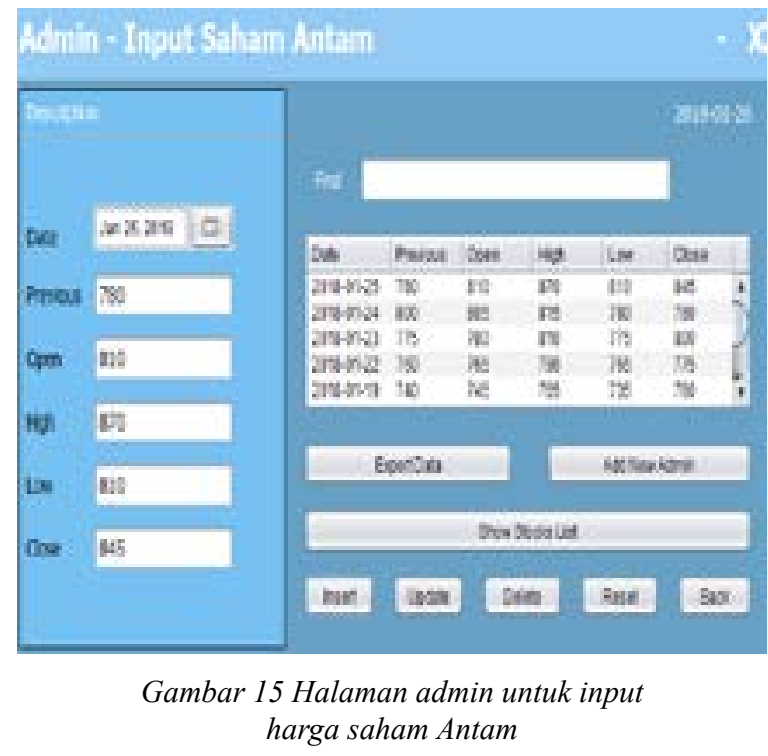

\section{Tampilan Halaman Utama User}

Halaman ini merupakan halaman dimana pengguna dapat melakukan berbagai aktifitas seperti melihat harga saham dan melakukan prediksi dengan menggunakan metode Simple Moving Avearge dan Linear Regression seperti pada Gambar 16. Pada tabel tersebut pengguna dapat membandingkan prediksi harga saham dengan menggunakan kedua metode yang tersedia.

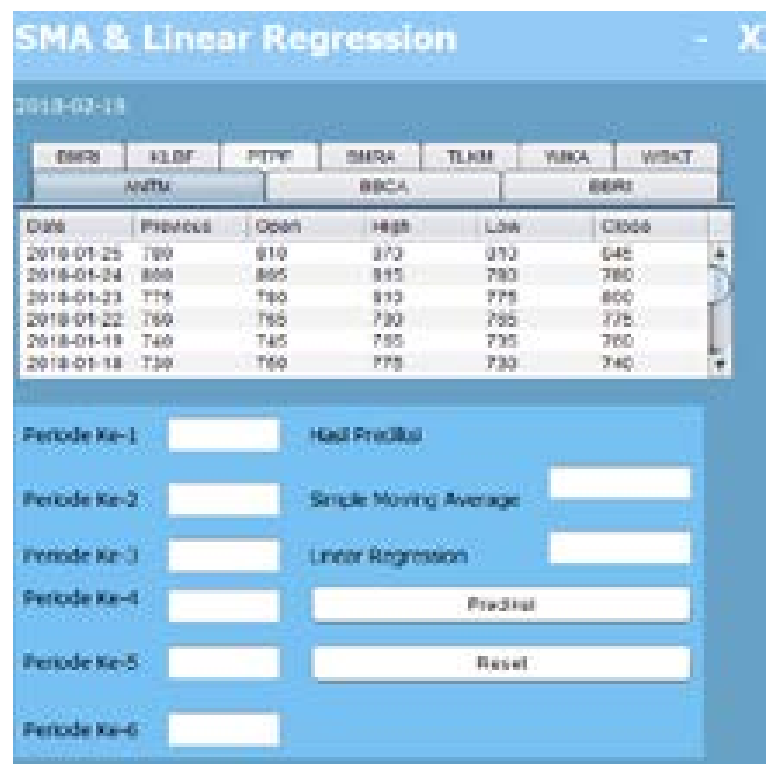

Gambar 16 Halaman utama user 


\section{J. Pengujian Tingkat Akurasi}

Pada Tahapan ini peneliti menguji tingkat akurasi dari kedua metode yang ada yaitu Simple Moving Average (SMA) dan Linear Regression (LR). Pengujian dilakukan dengan menggunakan sistem yang dibuat oleh peneliti berdasarkan data penutupan harga saham pada 6 periode sebelumnya dan akan dicari data hari berikutnya yang dapat dilihat pada Gambar 17

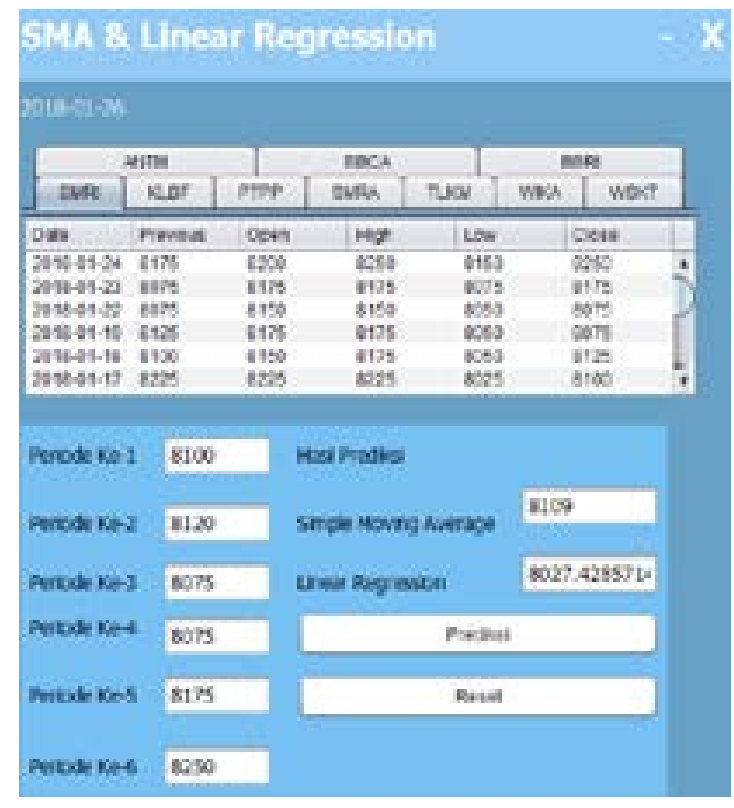

Gambar 17 Pengujian Sistem Peneliti

Pada Gambar 17 peneliti mengambil sample harga saham pada bank mandiri dengan kisaran waktu antara tanggal 17 Januari 2018 sampai dengan 24 Januari 2018. Pada Gambar 17 peneliti melakukan input data pada setiap penutupan harga saham dan menjadikan periode yang paling akhir yaitu periode ke 6 sehingga didapatkan data yang ada pada Tabel 2

Peneliti melakukan pengujian terhadap data saham, yaitu dengan menetapkan data penutupan sebagai kriteria yang akan dilakukan pengujian pada masing-masing harga saham seperti pada Tabel 2 , sehingga didapatkan data pada Tabel 3

Berdasarkan data pada Gambar 17 peneliti menguji akurasi dari setiap harga saham yang Tabel 2 Daa Saham Yang Akan Diuji

\begin{tabular}{|l|l|r|}
\hline Koce saham & \multicolumn{1}{|c|}{ Tanggat } & $\begin{array}{c}\text { Data } \\
\text { Testing }\end{array}$ \\
\hline ANTM & $2018-01-17-2018-01-24$ & 845 \\
\hline BBCA & $2018-01-16-2018-01-23$ & 22650 \\
\hline BBRI & $2018-01-16-2018-01-23$ & 3920 \\
\hline BMRI & $2018-01-17-2018-01-24$ & 8250 \\
\hline KUBF & $2018-01-17-2018-01-24$ & 1725 \\
\hline DTPD & $2018-01-10=2018-01-77$ & 3100 \\
\hline SMRA & $2018-01-17-2018-01-24$ & 1050 \\
\hline TLKM & $2018-01-10-2018-01-77$ & 4200 \\
\hline WCKT & $2018-01-17=2018-01-24$ & 2790 \\
\hline WIKA & $2018-01-17-2018-01-24$ & 20010 \\
\hline
\end{tabular}

Tabel 3 Hasil Penghitungan Simple Moving Average

\begin{tabular}{|c|c|c|c|c|c|c|}
\hline \multirow{2}{*}{$\begin{array}{l}\text { cede } \\
\text { Stham }\end{array}$} & \multirow[b]{2}{*}{ Taregy } & \multirow{2}{*}{$\begin{array}{c}\text { Dats } \\
\text { Testing }\end{array}$} & \multicolumn{4}{|c|}{ Matode 1} \\
\hline & & & sele & $W 0$ & $\begin{array}{c}\text { NABT } \\
(5)\end{array}$ & $\begin{array}{c}\text { Arsoluse } \\
\text { (O) }\end{array}$ \\
\hline $\mathrm{AmM}$ & 2048-01-19-301501-24 & 345 & $n 1$ & 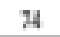 & 276 & 9224 \\
\hline$B: C 4$ & $2013.04: 5=201301 \cdot 23$ & 22550 & 2748 & 200 & CSB & $\$ 2.12$ \\
\hline 39: & $2018.04 \cdot 55 \cdot 200301.23$ & 390 & $\$ 200$ & 300 & 7,55 & 92.35 \\
\hline SNe & $2518-01,27+201501-24$ & 850 & nis & 101 & 11 & $\operatorname{ses}$ \\
\hline $0 \times 5$ & $2018.01 \cdot 17 \cdot 20130064$ & 136 & 1770 & 5 & 0.9 & $993 !$ \\
\hline PTD & $2018-01 \cdot 5 \cdot 2001501-77$ & 3100 & $2 \%$ & 104 & 175 & 9655 \\
\hline Sn:A & $201301.17 \cdot 200101 \cdot 24$ & 1050 & 1024 & 26 & 248 & $97 \leq 2$ \\
\hline now & 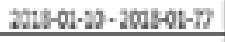 & $\angle 00$ & A: & 26 & S6 & 2214 \\
\hline wst & $2525-01-27-2001501-20$ & 20 & $26 \mathrm{~K}$ & 166 & $2 \leq 5$ & 34.41 \\
\hline Wra & $2013-01 \cdot 17 \cdot 20130104$ & $n 0$ & 1998 & 95 & 457 & 95.63 \\
\hline
\end{tabular}

terdapat pada sistem yang dibuat oleh peneliti dengan data testing, hasil Simple Moving Average dan Linear Regression pada setiap harga saham sebagai kriteria yang akan dilakukan pengujian. Peneliti menggunakan 2 metode pengujian akurasi, pertama dengan menggunakan Mean Absolute Deviation (MAD) dengan menggunakan rumus [18] yaitu.

$$
\mathrm{MAD}=\text { sma }- \text { data testing }
$$

Sehingga didapatkan hasil MAD pada setiap harga saham seperti pada Tabel 3 dengan menetapkan hasil SMA pada setiap harga saham dan data testing sebagai kriteria yang akan diuji. Kedua menggunakan metode Mean Absolute Percentage Error (MAPE) dengan menggunakan rumus seperti [19] yaitu.

$$
\text { MAPE }=\left(\frac{\text { MAD }}{\text { data testing }}\right) * 100
$$

Sehingga didapatkan hasil MAPE pada setiap harga saham seperti pada Tabel 3 dengan menetapkan hasil dari MAD pada setiap harga saham dan data testing sebagai kriteria yang akan diuji. Setelah didaptkan hasil tingkat kesalahan akurasi dengan metode Mean Absolute Deviation dan Mean Absolute Percentage Error, kemudian peneliti menguji persentase dari setiap data saham, yaitu mengurangi total persentase $(100 \%)$ dikurangi dengan hasil penjumlahan Mean Absolute Percentage Error dari setiap harga saham, yang kemudian didapatkan hasil persentase dari setiap harga saham.

\section{Persentase $=100 \%-$ MAPE}

Tabel 4 menggunakan metode yang sama dengan Tabel 3 yaitu berdasarkan dengan data pada Gambar 17 dari hasil tersebut maka didapatkan tingkat akurasi dan persentase dari masing-masing data saham.

Pada Tabel 5 peneliti menjumlah total akurasi berdasarkan penghitungan MAD dan MAPE untuk mengukur tingkat kesalahan akurasi dan mendapatkan hasil persentase berdasarkan data MAPE dikurangi data testing kemudian dikalikan dengan 100\% sehingga didapatkan hasil akurasi metode Simple 
Tabel 4 Hasil Penghitungan Linear Regression

\begin{tabular}{|c|c|c|c|c|c|c|}
\hline \multirow{2}{*}{$\begin{array}{l}\text { rode } \\
\text { Satan }\end{array}$} & \multirow[b]{2}{*}{ Tengas } & \multirow{2}{*}{$\begin{array}{l}\text { Data } \\
\text { sham }\end{array}$} & \multicolumn{4}{|c|}{ Matsde2 } \\
\hline & & & LR & MaD & $\begin{array}{c}\text { vast } \\
\text { (3) }\end{array}$ & $\begin{array}{c}\text { Fersentace } \\
89]\end{array}$ \\
\hline ATM & $201801.17 \cdot 201804 \cdot 24$ & 245 & $n 3$ & 232 & 1562 & 3439 \\
\hline BBCA & $201801-15 \cdot 201301 \cdot 23$ & 22550 & 22357 & 293 & 129 & 9871 \\
\hline 89) & $2018-01-15 \cdot 2018-0 ! \cdot 23$ & 3600 & 3491 & 429 & 1094 & 80.06 \\
\hline gUR & $20180 \mathrm{~L}-17 \cdot 20130 \mathrm{~L} \cdot 24$ & 800 & 800 & 223 & 2.00 & 9730 \\
\hline $\mathrm{x}: \mathbf{F}$ & $201801-17 \cdot 201301.24$ & 178 & $172 \mathrm{~s}$ & 1 & 0.06 & Ags \\
\hline$P T P$ & $201801-10 \cdot 2018-0 \mathrm{t}, n$ & 3100 & 2846 & 254 & 497 & 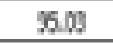 \\
\hline SMFA & $201801-17 \cdot 201301 \cdot 24$ & 100 & 2012 & 38 & 362 & 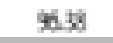 \\
\hline TLM & 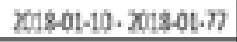 & $4 \times 0$ & 4351 & 85 & 1.17 & 92.33 \\
\hline WST & $201801-17 \cdot 2018.01 \cdot 24$ & 280 & 2600 & $2 B$ & 656 & 93.43 \\
\hline mas & $201801-17 \cdot 201301-24$ & 2000 & 1998 & 83 & 399 & sot \\
\hline
\end{tabular}

Tabel 5 Hasil Penghitungan Total Akurasi

\begin{tabular}{|c|c|c|c|c|}
\hline \multirow{2}{*}{$\begin{array}{c}\text { Kode } \\
\text { Saham }\end{array}$} & \multirow[b]{2}{*}{ Tanzgal } & \multirow{2}{*}{$\begin{array}{l}\text { Data } \\
\text { Saham }\end{array}$} & \multicolumn{2}{|c|}{ Total Akunsi } \\
\hline & & & $\begin{array}{l}\text { Persentast } \\
\text { SNA } 6 \text {. }\end{array}$ & $\begin{array}{c}\text { persertase } \\
\text { (R (R) }\end{array}$ \\
\hline ANTM & $2018-01-17 \cdot 2018-01-26$ & 815 & 91.24 & 34.38 \\
\hline BBCA & $2018-01-16 \cdot 2018.01-23$ & 22550 & 99.12 & 98.7 \\
\hline B8\%: & $201801-16 \cdot 2018-01-23$ & 3920 & 92.35 & 89.06 \\
\hline BNRI & $201801-17 \cdot 201801-24$ & 8250 & 98.29 & 97.30 \\
\hline KLAF & $2018 \cdot 01-17 \cdot 2018 \cdot 01-24$ & 1725 & 99.71 & 99.94 \\
\hline PTPP & $201801-10 \cdot 201801-77$ & 3100 & 96.65 & 95.03 \\
\hline SMAA & $2018-01-17 \cdot 2013 \cdot 01-24$ & 1050 & 97.52 & 96.38 \\
\hline TuOM & $2018-01 \cdot 10 \cdot 2018-01-77$ & 4500 & 92.14 & 98.83 \\
\hline WST & $2018-01-17 \cdot 2013-01-24$ & 2790 & 94.41 & 93,43 \\
\hline WKA & $2018-01-17 \cdot 2018-01-24$ & 2090 & 95.43 & 96,01 \\
\hline & & Tetal & $9.39 \%$ & $94.91 \mathrm{~K}$ \\
\hline
\end{tabular}

Moving Average dan Linear Regression seperti pada tabel 5 Kemudian untuk mendapatkan total akurase maka dijumlahkan total persentase Simple Moving Average dan Linear Regression dibagi dengan jumlah data saham yakini 10, sehingga didapatkan total akurasi untuk masing - masing metode yaitu $96.39 \%$ untuk metode Simple Moving Average dan 94.91\% untuk metode Linear Regression.

\section{SIMPULAN}

Dengan adanya aplikasi pendukung keputusan ini, dapat membantu pengguna khusus nya calon investor untuk memprediksi harga saham dengan metode Simple Moving Average dan Linear Regression. Dari pengujian sistem menunjukan Simple Moving Average memiliki tingkat akurasi sebesar 96.39\% dan Linear Regression memiliki tingkat akurasi sebesar 94.91\%. Metode Simple Moving Average memiliki akurasi yang lebih baik jika dibandingkan dengan Linear Regression. Dari hasil penelitian yang telah diselesaikan, peneliti berkesimpulan bahwa:(1)Berdasarkan hasil penelitian membuktikan tingkat akurasi Simple Moving Average sebesar 96.39\% Linear Regression sebesar 94.91\%. (2) Metode Simple Moving Average dan Linear Regression dapat digunakan untuk memprediksi harga pada pasar saham.(3)Simple Moving Avearge merupakan metode terbaik jika dibandingkan dengan Linear Regression karena memiliki tingkat akurasi yang lebih baik.

\section{DAFTAR RUJUKAN}

[1] G. Aranoff."Globalization: Alternative Pricing in a Peak-Load Pricing Model.”. hlm 889-896, 2017.

[2] E. Turban et al. Technology for Management Making Connection for Strategies Advantages 2nd Edition. John Wiley \& Sons Inc. 1999.

[3] E. Turban. Decision Support Systems and Intelligent System Edisi Bahasa Indonesia Jilid 1. Jakarta: Andi. 2005.

[4] A. S. Rini dan D. Soyusiawaty. "Sistem pendukung keputusan Seleksi Penerimaan Beras Untuk Keluarga Miskin Dengan Menggunakan Metode Simple Additive Weighting". Vol 2, NO.2, hlm 1196-1205, 2014.

[5] S. Pojoh et al. "Sistem Pendukung Keputusan Menentukan Siswa Berprestasi Yang Layak Menjadi Siswa Teladan”. Vol 2, NO.1, hlm 86-91, 2016.

[6] J. Prananda dan M. Y. Santoso. "Sistem Pendukung Pengambilan Keputusan Pembelian Mobil Baru Dengan Metode Logika Fuzzy". Vol 2, NO.1, hlm 8691, 2016.

[7] F. Irham. Analisis Laporan Keuangan, Bandung: Alfabeta. 2013. hlm 55.

[8] D. Septyanto. "Faktor - Faktor Yang Mempengaruhi Investor Individu Dalam Pengambilan Keputusan Investasi Sekuritas DI Bursa Efek Indonesia”. Vol 4, NO.2, hlm 90-101, 2013. 
[9] Y. Palimo. "Perbandingan Efisiensi Teknikal Indikator Simple Moving Average Dan Exponential Moving Average Pada Saham Pertambangan Batubara Di Bursa Efek Indonesia". 2012

[10] L. Sany dan H.Sarjono. "Peramalan Jumlah Siswa/I Sekolah Menengan Atas Swasta Menggunakan Enam Metode forecasting". Vol 10, NO.2, hlm 86-91, 2013.

[11] J. A. Hall. Accounting Information System 3rd Edition. South Western College Publishing. 2001.

[12] J. W. Wilkinson. Accounting and Information Systems. John Wiley \& Sons Inc. 1992.

[13] Turban et al. Decision Support and Business Intelligence Systems ninth Edition. Person Education Inc: New Jersey. 2011

[14] J. Hermawan. Membangun Decision Support System. Yogyakarta: Andi. 2005

[15] Qamirayanti et al. Hukum Pasar Modal di Indonesia. Jakarta : Sinar Grafika. 2009.

[16] Y. S. Juliati. "Peranan Pasar Modal Dalam Perekonomian Negara”. Vol 2, NO.1, hlm 95-112, 2015.

[17] M. F. Saputri dan S. Sudaryanto. "Analisa Data Penjualan Menggunakan Metode Regresi Linier Untuk Prediksi Persedian Barang Pada TB. Kawankita”.

[18] N. L. Kartikat et al. "Peramalan Permintaan Produk Perak Menggunakan Metode SImple Moving Average dan Exponential Smoothing". Vol 9, NO.01, hlm 97106, 2014.Y. S. Juliati. "Peranan Pasar Modal Dalam Perekonomian Negara". Vol 2, NO.1, hlm 95-112, 2015.

[19] K. Margi dan S. Pendawa. "Analisa dan Penerapan Metode Single Exponential Smoothing Untuk Prediksi Penjualan pada Periode Tertentu". hlm 259-266, 2015. 